\title{
PENINGKATAN BELAJAR MATEMATIKA TENTANG PENGERJAAN HITUNG BILANGAN BULAT MELALUI BERBAGAI MEDIA
}

\author{
Anita \\ Guru SDN 24 Teluk Batu, Kec, Nanga Pinoh Kab. Melawi
}

\begin{abstract}
To improve learning outcomes especially to accelerate the mastery of subject matter at elementary school level, the need for improvements in teaching and learning process through learning improvement program, especially in Mathematics subjects in order to obtain learning mastery. At Teluk Teluk State Elementary School, Kec, Nanga Pinoh Kab. Melawi found that students' learning outcomes were not appropriate for their absorption. Students were considered successful in classical learning when their absorption rate was $85 \%$ or more, and scored above 6.5. In accordance with the assessment technical guidance, if the student did not achieve the absorptive capacity $85 \%$ and scores below 6.5, educators classify these students as students with low learning outcomes. In the learning process that is conveyed to 20 students of class $V$ in daily examination, recorded students who master the subject matter with a value above 6.5 only 6 people (30\%) and 14 Orang students $(70 \%)$ have not been able to master the subject matter. During the learning process, the absence of students asking questions or responding to teacher explanations. Based on these findings, the authors asked colleagues to identify the shortcomings of the lessons learned.
\end{abstract}

Keywords ; Improvement, Improvement of Learning Process

\section{PENDAHULUAN}

Setelah didiskusikan dengan teman sejawat dan beberapa orang guru,maka rendahnya hasil belajar mata pelajaran Ilmu Pengetahuan Alam siswa kelas V Sekolah Dasar Negeri Teluk Batu, Kec, Nanga Pinoh Kab. Melawi dengan indicator "melakukan penjumlahan pengurangan bilangan bulat",terungkap beberapa masalah yang terjadi melalui diskusi dengan teman-teman mahasiswa dan dibantu oleh teman sejawat,terungkap bahwa factor penyebab siswa kurang menguasai materi pelajaran yang diajarkan oleh guru,antara lain adalah: Dari penelitian ini penulis berharap agar daya serap siswa secara klasikal dapat mencapai $85 \%$ dan hasil belajarnya menjadi meningkat bertolak dari latar belakang masalah dan tindakan yang dipilih,maka rumusan masalah yang penulis kemukakan adalah "bagaimana cara meningkatkan hasil belajar matematika tentang pengerjaan hitung bilangan bulat melalui berbagai media pada siswa kelas V SDN Teluk Batu, Kec,
Nanga Pinoh Kab. Melawi tahun 20162017.

Melalui perbaikan pembelajaran ini diharapkan akan dapat ditemukan terbaik untuk meningkatkan hasil belajar siswa,dan bermanfaan bagi guru dan sekolah,khususnya pada mata pelajaran Matematika di Sekolah Dasar Teluk Batu, Kec, Nanga Pinoh Kab. Melawi.

\section{METODE}

Jenis penelitian yang dilakukan adalah penelitian tindakan kelas yang dilaksanakan dalam beberapa siklus, yaitu siklus I dan seterusnya. Tahap-tahap pelaksanaan meliputi perencanaan, pelaksanaan, pengamatan dan refleksi. Media merupan suatu sarana pendidikan yang sangat membatu proses belajar mengajar terutama dalam hal penggunaan indera penglihatan.Media pembelajaran yang tepat dapat meransang siswa dan guru untuk menciptakan situasi proses pembelajaran yang baik jika di pakai dengan tepat. 
Media pembelajaran dapat membantu guru untuk menciptakan berbagai situasi kelas,menentukan metode pengajaran yang dipakai dalam situasi yang berlainan,dan menciptakan emosional yang sehat diantara muridmuridnya.Bahan pembelajaran ini selanjutnya membantu guru membawa dunia kedalam kelas.Dengan demikian ide yang abstrak dan asing sipatnya menjadi lebih konkrit dan mudah dimengerti oleh siswa.Bila pembelajar ini digunakan dengan tepat,maka siswa akan melibatkan diri dalam pembelajarannya ada kemungkinan mereka akan bertambah baik dan maju.(Robinson,1998).

Dari pendapat diatas dapat disimpukan bahwa media pembelajaran sangan diperlukan bagi guru sebagai alat Bantu untuk memperjelas semua pembahasan yang terkait dalam dalam proses belajar mengajar kelas.Guru yang profesional haruslah mampu memilih media pembelajaran yang tentu disesuaikan dengan usia peserta didik yang hendak diajar serta materi pembelajaran itu sendiri.

Hasil pembelajaran merupakan salah satu bentu penilaian dalam pelaksanaan kurikulum. Bahar,(1996) menggambarkan hasil belajar siswa dan daya capai kurikulum tiap akhir semester,bahwa ada dua hal yang sangat penting untuk dijadikan sarana evaluasi pelasanaan kurikulum,yaitu hasil belajar siswa tiap semester dan daya capai kurikulum pada tiap sekolah.Data hasil belajar siswa sangat diperlukan oleh guru untuk mengetahui keterbatasan belajar siswa dikelas yang menjadi tanggung jawabnya.

Berdasarkan pengetahuan dan pengalaman penulis bahwa pelaksanaan proses belajar mengajar tanpa menggunakan media menyebakan hasil belajar siswa yang diharapkan menjadi tidak memuaskan.Hal ini terbukti dari setiap dilaksanakan tes,haya sebagian siswa yang mampu menjawabnya dengan benar.

Upaya yang yang dapat dilakukan untuk mengatasi permasalahan di atas adalah dengan melakukan kegiatan mengajar dengan meransang indera siswa melalui pemakaian media konkrit atau semi konkrit.Willem,(1989) dalam bukunya " Menjadi Guru yang Profesional" mengatakan bahwa mengajar adalah membimbing kegiatan belajar siswa agar ia mampu belajar.Lebih lanjut Jhonson dan Rissing juga menyatakan bahwa orang dapat mengingat sekitar 20\% dari yang didengarnya,50\% dari yang dilihatnya, $75 \%$ dari yang diperbuatnya.

Berdasarkan beberapa pernyataan diats dapat disimpulakan bahwa belajar dengan berbuat akan lebih bermanfaat dan lebih bermakna dari pada belajar dengan mendengar saja.Sesuai dengan permasalahan yang dihadapi dalam pembelajaran Matematika Kelas V dengan materi pembelajaran hitung bilangan bulat maka pengetahuan tentang benda konkrit atau semi konkrit akan sangat membantu dalam menentuakan hasil belajar siswa.

\section{Subjek penelitian}

Penelitian yang dilakukan dalam bentuk perbaikan pembelajaran Matematika Kelas V di Sekolah Dasar Negeri Teluk Batu, Kec, Nanga Pinoh Kab. Melawi jumlah siswa 20 orang,dengan tingkat kemampuan dan daya serap siswa serta karakteristik sangat bervariasi.Pelaksanaan perbaikan ini dilakukan oleh Guru Sekolah Dasar Negeri Teluk Batu, Kec, Nanga Pinoh Kab. Melawi,

\section{Pelaksanaan.}

Guru menginformasikan pelaksanaan pembelajaran tentang pengerjaan hitung bilangan bulat,dan siswa mengerjakan daftar penjumlahan dan pengurangan bilangan bulat yang dipasang guru dipapan tulis. Guru meminta kepada siswa untuk mendiskusikan pengerjaan hitung bilangan bulat dan kemudian mengerjakan soal-soal latihan.Kalau sudah betul diberikan penguatan materi.Guru bersama siswa merangkum materi .dan kemudianguru memberikan tugas dirumah membaca materi yang akan dibahas pada pertemuan berikutnya.

Dalam pelaksanaan perbaikan pembelajaran siklus pertama ini masih banyak siswa yang merasa masih kebingungan dalam mengerjakan tugas ini.Hal ini terbukti dari 20 siswa,hanya 6 orang yang berani tampil di depan kelas.Melalui hasil observasi 
pembelajaran yang dilakukan oleh teman sejawat menyataka bahwa siswa tidak mengerti tentang apa yang dijelaskan oleh guru.Kendala lain yang ditemukan adalah waktu yang alokasikan untuk proses pembelajaran tidak mencukupi sehingga perbaikan pembelajaran belum dapat dilaksanakan sesuai waktu yang telah dialokasikan.

Pada siklus kedua tindakan teman sejawat selalu observasi telah sesuai dengan yang direncanakan.Waktu yang tersedia untuk melaksanakan tindakan sudah sesuai dengan alokasinya.Kehadiran observasi tidak lagi memperngaruhi proses pembelajaran.

Berdasarkan hasil observasi ditemukan adanya kenaikan hasil belajar siswa,yakni siswa yang memperoleh nilai 5 pada tes awal, sudah menunjukan adanya peningkatan hinggga memperoleh nilai di atas 5 pada tes akhir.Dengan demikian,media pembelajaran mempunyai dampak positif pada peningkatan hasil belajar.

Keberanian siswa kedepan kelas untuk mengidentifikasi kondisi yang mempengaruhi kenaikan dari 6 orang anak ( 30\%) pada kondisi awal,menjadi 11 orang anak (55\%) pada siklu 1,atau mengalami peningkatan $25 \%$ dari kondisi awal.Keberanian siswa untuk mengajukan pertanyaan masih sangat rendah.Pada pertemuan ini hanya 6 orang yang berani bertanya,sementara siswa lainnya terlihat masih tanpak ragu-ragu.

Pada siklus kedua hasil analisis data yang dilaksanakan secara umum telah menunjukan adanya peningkatan dan keberhasilan.Keberhasilan belajar siswa ini ditunjukan adanya perolehan nilai siswa diatas 6.5 ,dari 11 orang $(55 \%)$ menjadi 20 orang $(100 \%)$,mengalami kenaikan $70 \%$ dari perbaikan pembelajaran siklus pertama.Pembelajaran pada siklus kedua secara umum mulai membaik,hal ini terlihat dengan adanya interaksi yang semakin akrab dari segala arah.Perolehan hasil belajar siswa secara unum dari setiap siklus,

Tabel 2

Distribusi Hasil Belajar Siswa

\begin{tabular}{llllllllll}
\hline \multirow{2}{*}{ No SKOR } & \multicolumn{2}{l}{ SIKLUS II } & \multicolumn{4}{c}{ SIKLUS II } & \multicolumn{3}{c}{ SIKLUS III } \\
\cline { 2 - 11 } & $\mathbf{F}$ & $\%$ & SxF & $\mathbf{F}$ & $\mathbf{\%}$ & $\mathbf{S x F}$ & $\mathbf{F}$ & $\boldsymbol{\%}$ & $\mathbf{S x F}$ \\
\hline JUMLAH & 20 & 100 & 1110 & 20 & 100 & 1380 & 20 & 100 & 1920 \\
\hline RATA-RATA & & & 55.50 & & & 69.00 & & 96.00 \\
\hline
\end{tabular}

Keterangan :

$\mathrm{SxF}=$ Skor $\mathrm{x}$ Frekwensi

Skor rata-rata kondisi awal (Siklus I) $=$ 1110

Skor rata-rata Siklus II $=\quad 1380$

Skor rata-rata Siklus III

$=$

$=\quad 1920$

$=\quad 96.00$

\section{Refleksi}

Reflesi lengkap dari siklus pertama dan di dukung dengan jurnal harian guru,terungkap beberapa harapan,antara lain: Waktu yang di alokasikan untuk perbaiakan pembebelajaran tidak cukup,karena tersita untuk menjelaskan

konsep. Suasana pembelajaran kelihatan agak tegang dan terkesan kaku.Hal ini disebabkan adanya guru lebih dari satu dalam kelas (guru lain sebagai observer) yang biasanya tidak pernah ada.sehingga konsentrasi siswa tidak sepenuhnya terpusat pada materi 
pembelajaran,akan tetap sekali siswa malahan memperhatikan kinerja observer.

Berdasarkan hasil pengamatan yang telah dilakukan,disaran kepada guru agar dapat meningkatkan kemampuan mengajar dengan cara memberikan konsep-konsep dengan cara yang mudah agar siawa cepat mengerti serta memahami penjelasan guru.Guru juga diharapkan terampil dalam menggunakan media agar proses pembelajaran dapat berjalan dengan baik. Di samping itu, kehadiran obsever disosialisasikan terlebih dahulu kepada siswa agar keberadaannya tidak menimbulkan perasaan was-was bagi para siswa.

Hambatan yang masih di temukan pada siklus kedua dan alternative pemecahan: Siswa sudah terlibat aktif untuk mengidentifikasi berbagai bentuk soal pengerjaan hitung bilangan bulat,akan tetapi timbul masalah kelas menjadi gaduh dan rebut.Alternatif pemecahan masalah ini :siswa yang akan di tunjuk kedepan kelas adalah siswa

yang duduknya paling rapid an tidak bersuara. Siswa yang mengacungkan tangan,dan tidak ditunjukan untuk kedepan biasanya akan merasa kurang puas. Alternatif pemecahannya adalah memberikan pengarahan dan pujian kepada mereka telah berani untuk unjuk kerja.

\section{HASIL DAN PEMBAHASAN}

Untuk mengetahui kondisi awal pembelajaran Matematika Kelas V Sekolah Dasar Negeri Teluk Batu, Kec, Nanga Pinoh Kab. Melawi,dilaksanakan tes awal dan pemberian angket pada siswa.Dari hasil angket dan tes awal secara umum keadaannya menunjukkan : Kuranya pengetahuan siswa tentang cara mengidentifikasi pengerjaan hitung bilangan bulat. Kurangnya pengetahuan untuk dapat menjelaskan cara termudah pengerjaan hitung bilangan bulat. Kesulitan siswa menjelaskan cara-cara pengerjaan hitung bilangan bulat. Kuranya tugas-tugas yang diberikan guru tentang cara mengidentifikasi pengerjaan hitung bilangan bulat. Dari tes awal tentang pengajian pengerjaan hitung bilangan bulat,diperoleh data bahwa 20 orang siswa yang ikut tes,14 siswa (70\%) mendapatkan nilai kurang dari 6.5 dan hanya 6 orang siswa (30\%) yang mendapat nilai diatas 6.5 ( ukuran belajar tuntas individual ).Denagan demikian,pengetahuan awal siswa tentang pengerjaan hitung bilangan bulat,masih sangat rendah,dan perlu dilakukan perbaikan pembelajaran.

Berdasarkan hasil refleksi, observasi, dan penelitian pada siklus pertama,maka pada siklus kedua merupakan kelanjutan dari siklus pertama.Pokok bahsan yang disajikan juga berbeda,yaitu cara mengidentifikasi pengerjaan hitung bilangan bulat.permasalahan yang ditemukan pada siklus pertama diperbaiki pada siklus kedua.

Model pembelajaran dengan menggunakan metode penugasan dengan cara pemanfaatan media dalam pengerjaan hitung bilangan bulat,sangat menarik bagi siswa.Model ini dapat meningkatkan kreatifitas dan keberanian siswa,juga rasa percaya diri guru dalam proses pembelajaran.Penggunaan metode ini menyangkut tiga aspek,yaitu : 1) ranah afektif; 2) ranah kognitif; dan 3) ranah psikomotorik.Pembelajaran seperti ini akan memudahkan bagi siswa untuk mengingat materi pembelajaran Matematika yang berkaitan dengancara pengerjaan hitung bilangan bulat.

Hasil penelitian pembelajaran ini terbatas hanya pada kemampuan siswa dalam pengerjaan hitung bilangan bulat.Sedangkan tugas yang diberikan hanya cara mengidentifikasi pengerjaan hitung bilangan bulat.sedangkan penilaian berdasarkan kebenaran ( kutipan ) benda konkrit yang disesuaikan berdasarkan benda semi konkrit yang dipajangkan guru di papan tulis hasil pikirannya sendiri atau ditunjukan oleh teman yang lain.Guru memotivasi siswa bagi merekayang mau tampil ke depan diberi poin.Waktu yang tersedia untuk melakukan penelitian sangat singkat sekali,sehingga hasil penelitian kurang sempurna.

\section{KESIMPULAN DAN SARAN Kesimpulan}

Bertitik tolak dari tindakan yang telah dilakukan pada perbaikan pembelajaran ini,maka kesimpulan yang dapat ditemukan adalah sebagai berikut : (1) media konkrit atau semi konkrit dapat meningkatkan hasil belajar siswa. Media konkrit atau semi konkrit mendorong guru untuk meningkatkan 
kemampuan penugasan materi pelajaran,dan dapat meningkatan kreatifitas guru dalam membuat model - model pembelajaran. (2) Media Konkrit atau semi konkrit dapat mengaktifkan dan mengajak siswa untuk menemukan sendiri materi pembelajaran. Guru sudah tidak merupakan faktor dominan lagi dalam proses pembelajaran,dan guru telah berfungsi sebagai fasilitator dan dinamisator kelas.

\section{Saran}

Berdasarkan kesimpulan di atas,maka disarankan : Agar setiap guru yang menyampaikan pembelajaran Matematika tentang cara pengerjaan hitung bilangan bulat selalu menyajikannya dengan menggunakan alat peraga/media. Agara guru selalu menyiapkan tugas siswa secara terstruktur.

\section{DAFTAR RUJUKAN}

FKIF-UT.(2007),Pemantapan Kemampauan Profesional.Jakarta: Universita Terbuka.

I.G.A.K. Wardani, dkk. (2007).Teknik Menulis Karya Ilmiah. Jakarta : Universitas Terbuka.

I.G.A.K. Wardani, dkk. (2007). Penelitian Tindakan Kelas. Jakarta : Universitas Terbuaka.

Madya,S. (1994 ).Panduan Penelitian Tindakan Kelas. Yogyakarta :

Usman,M.U. (1990) Menjadi Guru

Profesional.Bandung : PT.Remaja

Rosda Karya. 